\title{
Pharmacokinetic profile and some pharmacodynamic aspects of cefquinome in chickens
}

\author{
A. A. M. El-Gendy ${ }^{*}$, M. A. Tohamy, Abeer M. Radi \\ Deparment of Pharmacology, Faculty of Veterinary Medicine, Beni-Suef University, Beni-Suef \\ 62511, Egypt.
}

\begin{abstract}
The pharmacokinetic profile and some pharmacodynamic aspects of cefquinome were studied after intramuscular (IM) and subcutaneous (SC) administration of a single dose of $2 \mathrm{mg} \mathrm{kg}^{-1} \mathrm{~b} . \mathrm{wt}$. in chickens. Tissue distribution and residues of cefquinome after repeated IM injection for 5 consecutive days were also estimated. Cefquinome was rapidly absorbed after IM and SC injection as indicated by short half-lives of absorption $\left(\mathrm{t}_{0.5(\mathrm{ab})}\right)$ of 0.170 and $0.262 \mathrm{~h}$., respectively, while the elimination half-lives $\left(t_{0.5(\mathrm{el})}\right)$ were 3.428 and 25.023 h., respectively. Repeated IM doses of cefquinome ( $2 \mathrm{mg} \mathrm{kg}^{-1} \mathrm{~b}$.wt., once daily) for 5 consecutive days caused no change in serum enzyme activities of ALT and AST, but induced significant increase in serum uric acid concentration after 72 to 120 hours of administration. The withdrawal time of cefquinome from tissue of chickens is 5 days following the last dose. Cefquinome has a wide spectrum of activity against Esherchia coli, Proteus mirabilis and Pseudomonas aeroginosa.
\end{abstract}

The cephalosporins are well-known and very useful classes of antibacterials, widely used in veterinary medicine for preventing and treating bacterial infections (Becker et al., 2004). They are described as $\beta$-lactam antibiotics, based on their common chemical structure, containing the $\beta$-lactam ring. A major advantage of the $\beta$-lactam antibiotics is their high degree of safety in the target animal (Preston, 1992). Cefquinome, an aminothiazolyl cephalosporin and a member of the $4^{\text {th }}$ generation of cephalosporins which have been developed especially for use in animals, has a very broad spectrum of activity against many bacteria (Guerin-Faublee et al., 2003). The in vitro and in vivo efficacy of this drug against a wide range of gram-negative and gram-positive bacteria has been demonstrated by Limbert et al., (1991). In comparison with the third generation cephalosporins, cefquinome showed a higher activity against Gram-negative bacteria and a lower affinity for plasmid-mediated cephalosporinases (Suhren and Knappstein, 2003 and Rose et al., 2004).

The aim of the present work is under taken to study the pharmacokinetics of cefquinome after single intramuscular and subcutaneous dosage in chickens. Studying the tissue residues of the drug after the repeated IM doses and its effect on liver and kidney functions and the effect on some field bacterial isolates affecting chickens were also investegated.

* Corresponding author. Tel.: +20 0822322066; fax: +20822327982 .

E-mail address elgendy@bsu.edu.eg (Abdel-Nasser El Gendy).
Material and methods

Drugs. Cefquinome was obtained from Intervet International Company, Cairo, Egypt as 2.5 cefquinome suspension in ethyl oleate $\left(\right.$ Cobactan $\left.^{\circledR} 2.5 \%\right)$.

Chickens. Twenty four birds of both sexes with an average body weight from $1.280-2.800 \mathrm{~kg}$ and from 4-12 months old were used for pharmacokinetic studies and twenty four one-day old Fayoumy chicks were used for pharmacodynamic studies. These birds were obtained from El-Azab project for poultry production in Fayoum Governorate. The chickens were fed on balanced commercial ration and water ad-libitum. They were kept under good hygienic conditions and left for 15 day before the experiment for acclimatization and ensuring complete clearance of any antibacterial drugs.

Experimental protocol. Single dose pharmacokinetic studies were done on twenty four chickens which classified into two groups (each of 12 chickens). The $1^{\text {st }}$ group was administered cefquinome in a single dose of 2 mg kg ${ }^{-1}$ b.wt. (Block, 1996) by intramuscular route while, the $2^{\text {nd }}$ group administered cefquinome in a single dose of $2 \mathrm{mg} \mathrm{kg}^{-1}$ b.wt. by subcutaneous route. Blood samples $(1 \mathrm{ml}$ each) were withdrawn from the wing vein just before and $0.083,0.167,0.25,0.5,1,2,4,6,8,12$ and 24 hours post drug administration. Blood samples were left to clot then centrifuged at 3000 rpm for 15 minutes to obtain clear serum that was kept frozen at $-20{ }^{\circ} \mathrm{C}$ until assayed. 
Repeated dose pharmacokinetics were performed on 24 chickens given $2 \mathrm{mg} \mathrm{kg}^{-1}$ b.wt cefquinome intramuscularlly once daily for five successive days. The blood samples were collected just before and 1 hour after dose (peak and trough). Three chicken were slaughterd at 4,8,12,24 hours and $7^{\text {th }}, 8^{\text {th }}, 9^{\text {th }}, 10^{\text {th }}$ days after the last dose.

Blood and tissue samples (lung, spleen, liver, kidney, breast, thigh muscle and intestine) were taken from the slaughtered chicken. One gram was taken from each tissue sample, then was thoroughly homogenized in $4 \mathrm{ml}$ distilled water. Then homogenized tissue was centrifuged at at 3000 revolution per minute for 15 minutes. The supernatent was transferred to sterilized tubes to be used in the assay of concentration. The serum collected from blood samples were divided into two portion, the first to be used in the assay of concentration and the second for biochemical studies. The effect of the drug on the activities of ALT and AST and concentration of uric acid were estimated according to Reitman and Frankle (1957) and Kageyama, (1971), respectively.

Bacteriological samples were taken from 50 one-day old chicks for isolation of pathogenic bacteria according to Collee et al., (1996). The microorganisms isolated from the chicks were examined for antimicrobial sensitivity against cefquinome using the disc and agar diffussion method as described by Collee et al., (1996). All the suspected microorganisms were subjected to serotyping by slide agglutination test using standard polyvalent and monovalent E. coli antisera and according to the method described by Edwards and Ewing (1972). The minimum inhibitory (MIC) and minimum bactericidal concentrations (MBC) were estimated according to Collee et al., (1996).

Drug bioassay. Samples were assayed by microbiological assay according to the method of Arret et al., (1971) using Micrococcus luteus (ATCC 9341) as a test organism (San Martin et al., 1998). Standard cefquinome concentrations of $0.625,1.25,2.5,5,10,20$ and $40 \mathrm{ug} \mathrm{ml}^{-1}$ were prepared in antibiotic-free chicken's serum and also in distilled water. Semi-logarithmic plots of the inhibition zone diameter versus standard cefquinome concentrations in serum and distilled water were linear with typical correlation coefficient of 0.989 (for the standard curve). The difference of inhibition zone diameter between the solutions of the drug in serum and distilled water was used to calculate the in-vitro protein binding tendency of both drugs according to Lorian, (1980) by the following equation:

Protein binding $\%=$ [Zone of inhibition in buffer - Zone of inhibition in serum] $X$ 100/Zone of inhibition in buffer

Pharmacokinetic analysis. Serum concentration $\left(\log _{10}\right)$ versus time curves were generated and best fitted by the aid of computer polyexponential curve stripping program (R- strip, Micromath, Scientific software, USA). Data from each animal were fitted individually and the pharmacokinetic variables were computed by the aid of the software program. The first order absorption and elimination rate constants $\left(\mathrm{K}_{\mathrm{ab}}\right.$ and $\mathrm{K}_{\mathrm{el}}$ ) and the corresponding extrapolated zero time intercepts (A and $\mathrm{B})$, elimination and absorption half lives $\left(\mathrm{t}_{0.5(\mathrm{el})}\right.$ and $\left.\mathrm{t}_{0.5(\mathrm{ab})}\right)$, mean residence time (MRT), maximum serum concentration $\left(\mathrm{C}_{\max }\right)$ and time to be achieved $\left(t_{\max }\right)$ were also estimated. The area under the serum concentration-time curve (AUC) was calculated by trapezoidal rule. Results were expressed as mean and standard error (S.E). Standard errors were calculated from the mean data according to Snedecor, (1969).

\section{Results}

The diagrammatic relation between the time and the observed concentrations of cefquinome after IM and SC administration of $2 \mathrm{mg} \mathrm{kg}^{-1}$ b.wt were demonstrated in figure (1). The pharmacokinetic parameters of cefquinome after IM and SC routes are presented in table (1).

Following intramuscular and subcutaneous injections, cefquinome was rapidly absorbed with a half-lives of absorption ( $\left.\mathrm{t}_{0.5(\mathrm{ab})}\right)$ of 0.170 and $0.262 \mathrm{~h}$ and the peak serum concentrations $\left(\mathrm{C}_{\max }\right)$ were 12.421 and $4.935 \mathrm{ug} \mathrm{ml}{ }^{-1}$, respectively. The elimination half-lives $\left(\mathrm{t}_{0.5(\mathrm{el})}\right)$ were 3.428 and 25.023 h., respectively. In-vitro protein binding percent in chicken's serum ranged from 2.89-18.27 (mean 6.67) \%.

Serum concentrations of cefquinome following multiple intramuscular administration of $2 \mathrm{mg} \mathrm{kg}^{-1}$ b.wt. in chickens for 5 consecutive days were illustrated in figure (2). Multiple dose studies have demonstrated that cefquinome was cumulative over 5 days with a 24 hour dosing regimens. Table (2) demonstrate the serum and tissue concentration of the drug after multiple dosing. Cefquinome was not detected in any tissues except kidney after 120 hours following the last dose. Repeated IM administration of cefquinome ( $2 \mathrm{mg} \mathrm{kg}^{-1}$ b.wt once daily) for 5 consecutive days caused no change in serum enzyme activities of ALT and AST, but induced a significant increase in concentration of serum 
Table (1): Mean ( \pm SE) kinetic parameters of cefquinome $\left(2 \mathrm{mg} \mathrm{kg}^{-1} \mathrm{~b} . \mathrm{wt}\right)$ following a single IM and $S C$ administration in chickens $(n=12)$.

\begin{tabular}{|c|c|c|c|}
\hline Parameter & Unit & I.M & S.C \\
\hline $\mathbf{k}_{\mathrm{ab}}$ & $h^{-1}$ & $4.248+0.256$ & $3.290+0.426$ \\
\hline $\mathbf{K}_{\mathrm{el}}$ & $h^{-1}$ & $0.226 \pm 0.020$ & $0.035 \pm 0.005$ \\
\hline $\mathbf{t}_{0.5(a b)}$ & $\mathbf{h}$ & $0.170 \pm 0.011$ & $0.262 \pm 0.042$ \\
\hline $\mathbf{t}_{0.5(\mathrm{el})}$ & h & $3.428 \pm 0.374$ & $25.023 \pm 3.28$ \\
\hline $\mathbf{C}_{\max }$ & ug ml $\mathbf{~}^{-1}$ & $12.421 \pm 0.753$ & $4.935 \pm 0.270$ \\
\hline $\mathbf{t}_{\max }$ & h & $0.227 \pm 0.007$ & $0.292 \pm 0.022$ \\
\hline $\mathbf{A U C}$ & ug ml ${ }^{-1} h^{-1}$ & $17.585 \pm 0.815$ & $5.599 \pm 0.306$ \\
\hline MRT & h & $3.636 \pm 0.421$ & $20.680 \pm 4.615$ \\
\hline
\end{tabular}

$\mathrm{k}_{\mathrm{ab}}$ first-order absorption rate constant; $\mathrm{K}_{\mathrm{el}}$ elimination rate constant; $\mathrm{C}_{\max }$ maximum serum concentration; $\mathrm{t}_{\max }$ time to peak serum concentration; $\mathrm{t}_{0.5(\mathrm{ab})}$ absorption half-life; $\mathrm{t}_{0.5(\mathrm{el})}$ elimination half-life; MRT mean residence time; $\mathrm{AUC}_{0-12}$ area under serum concentration-time curve.

Table (2): Mean serum and tissue concentrations $\left(\mathrm{ug} \mathrm{ml}^{-1}\right)$ of cefquinome $\left(2 \mathrm{mg} \mathrm{kg}^{-1} \mathrm{~b} . w \mathrm{t} \mathrm{twice}\right.$ daily) in chickens after the last dose of repeated IM doses $(n=3)$.

\begin{tabular}{lcccccc}
\hline & \multicolumn{7}{c}{ Time of slaughter } \\
\cline { 2 - 7 } & $\mathbf{4 ~ h}$ & $\mathbf{8 ~ h}$ & $\mathbf{1 2} \mathbf{~ h}$ & $\mathbf{2 4} \mathbf{~ h}$ & $\mathbf{7 2} \mathbf{~ h}$ & $\mathbf{1 2 0} \mathbf{~ h}$ \\
\hline Serum & $2.09 \pm 0.69$ & $1.31 \pm 0.20$ & $1.02 \pm 0.17$ & $1.69 \pm 0.29$ & $0.352 \pm 0.35$ & $\mathrm{ND}$ \\
Liver & $7.312 \pm 0.43$ & $5.631 \pm 0.57$ & $3.616 \pm 0.25$ & $2.82 \pm 0.032$ & $2.098 \pm 0.22$ & $\mathrm{ND}$ \\
Kidney & $5.167 \pm 0.72$ & $4.67 \pm 0.13$ & $3.709 \pm 0.10$ & $2.226 \pm 0.87$ & $1.908 \pm 0.66$ & $0.149 \pm 0.15$ \\
Spleen & $3.708 \pm 0.34$ & $2.73 \pm 0.21$ & $2.184 \pm 0.13$ & $1.385 \pm 0.31$ & $\mathrm{ND}$ & $\mathrm{ND}$ \\
Lung & $5.826 \pm 1.96$ & $4.869 \pm 0.77$ & $3.709 \pm 0.59$ & $2.488 \pm 0.34$ & $0.258 \pm 0.26$ & $\mathrm{ND}$ \\
Intestine & $5.331 \pm 1.083$ & $4.083 \pm 1.16$ & $3.965 \pm 0.47$ & $1.974 \pm 1.09$ & $2.018 \pm 0.42$ & $\mathrm{ND}$ \\
Breast muscle & $5.572 \pm 1.52$ & $4.825 \pm 1.13$ & $3.386 \pm 0.31$ & $2.103 \pm 0.50$ & $\mathrm{ND}$ & $\mathrm{ND}$ \\
Thigh muscle & $\mathrm{ND}$ & $\mathrm{ND}$ & $2.258 \pm 0.81$ & $\mathrm{ND}$ & $\mathrm{ND}$ & $\mathrm{ND}$ \\
\hline
\end{tabular}

$\mathrm{ND}=$ Not detected
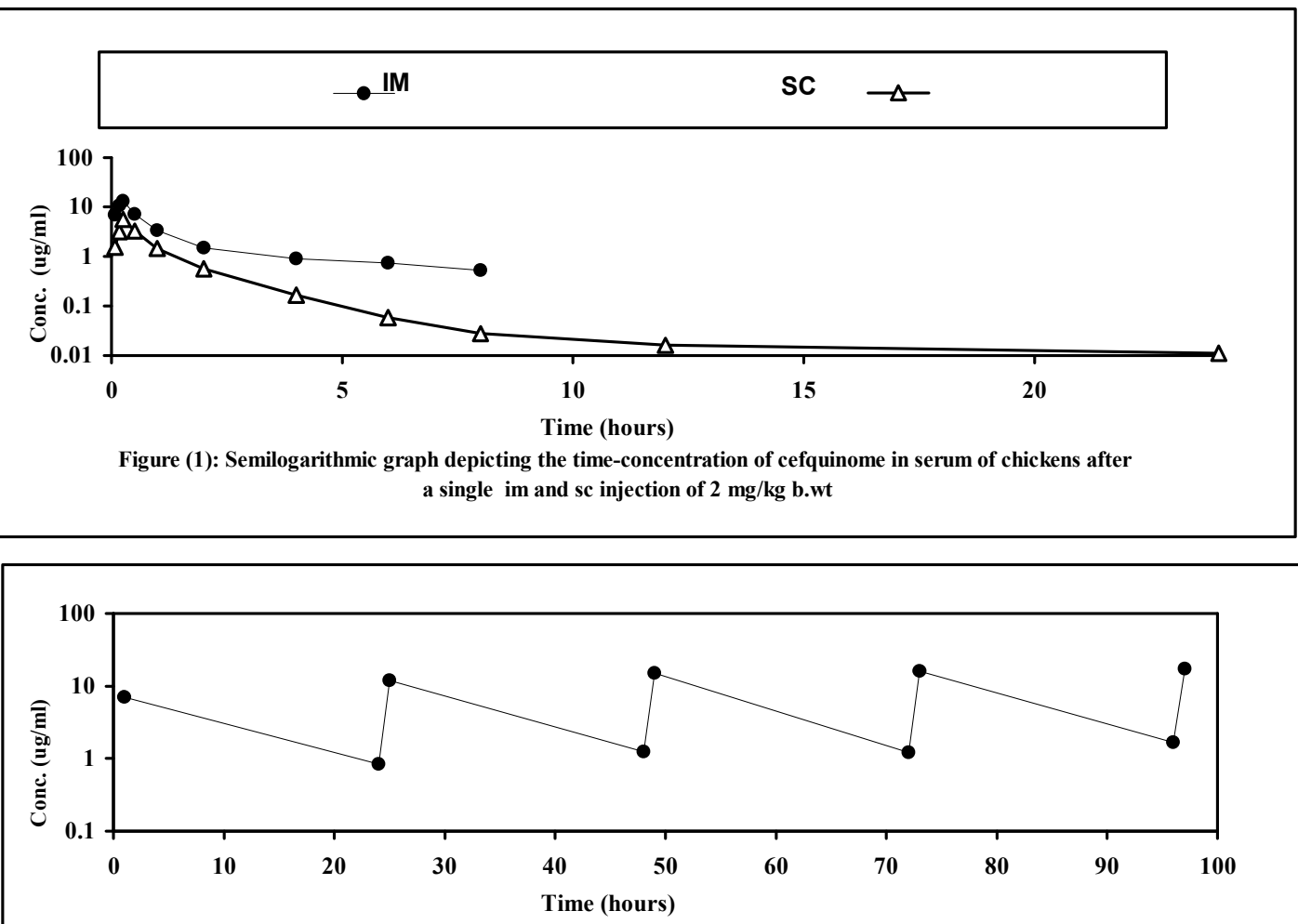

Figure (2) : Semilogarithmic plot depicting the time-course of cefquinome in serum of chickens after repeated intramuscular injection of $2 \mathrm{mg} \mathrm{kg}^{-1}$ b.wt. once daily for 5 consecutive days 
uric acid at 72 to 120 hours of administration.

From the bacteriological study, the microorganisms recovered from the chicks were Escherchia coli O78 serogroup, Proteus mirabilis and Pseudomonas aeroginosa. Cefquinome at concentration of (10 ug/well) inhibited the growth of all examined microorganisms. The minimum concentrations of cefquinome which inhibited the growth of Escherchia coli O78, Proteus mirabilis and Pseudomonas aeroginosa were $0.5,1$ and $16 \mathrm{ug}$ $\mathrm{ml}^{-1}$. The minimum bactericidal concentrations (MBC) of cefquinome which killed the tested microorganisms were 1,16 and $>128 \mathrm{ug} \mathrm{ml}^{-1}$.

\section{Discussion}

Following intramuscular injection of cefquinome in a single dose of $2 \mathrm{mg} \mathrm{kg}^{-1}$ b.wt, the drug was rapidly absorbed with an absorption half-life $\left(\mathrm{t}_{0.5(\mathrm{ab})}\right) 0.170 \mathrm{~h}$ and slowly eliminated with an elimination half-life $\left(\mathrm{t}_{0.5(\mathrm{el})}\right) 3.428 \mathrm{~h}$. These finding were similar to those reported by Maha, (2005), 0.153 and 4.84 h., respectively. The study recorded long elimination half-life $\left(\mathrm{t}_{0.5(\mathrm{el})}\right)$ of cefquinome after subcutaneous injection $25.023 \mathrm{~h}$. After repeated intramuscular injection of a dose $2 \mathrm{mg} \mathrm{kg}^{-1}$ b.wt once daily for 5 consecutive days, the results indicated that cefquinome was accumulated in the body. The drug was detected in most examined tissues up to $72 \mathrm{~h}$ after the last dose. It has been shown that cefquinome was poorly bound to plasma protein $(6.665 \%)$ which is similar to that reported by Limbert et al., (1991) in mouse, dog, horse and calf which less than $10 \%$. The rapid absorption and lower protein binding of cefquinome after intramuscular injection gave the ability to induce rapid effect by this route and may explain high diffusion of the drug in tissues of chickens.

In this study, the drug concentrations of cefquinome in serum exceeded the MIC of $E$ Coli and Proteus mirabilis, but less than the MIC of pseudomonas aeroginosa. Cruichshank et al., (1975) considered that a bacterium may be sensitive to antibiotic if the MIC is not more than 0.25-0.5 its average concentration in blood.

It could be concluded that cefquinome has advantageous pharmacokinetic profile following its $\mathrm{I} / \mathrm{M}$ administration to chickens at $2 \mathrm{mg} \mathrm{kg}^{-1}$ b.wt. Moreover, it has a wide spectrum of activity against Esherchia coli O78, Proteus mirabilis and Pseudomonas aeroginosa. In addition, it does not produce hepatic toxicity, but causes mild renal toxicity.

\section{References}

Arret, B.; Johnoson, D. P. and Kirshaum, A. (1971): Outline of details of microbiological assay of antibiotics: Second revision: J. Pharmaceut. Sci., 60: 1489-1694.

Becker, M.; Zittlau, E. and Petz, M. (2004): Residue analysis of 15 penicill-ins and cephalosporins in bovine muscle, kidney and milk by liquid chromato-graphy-tandem mass spectrometry. Analytica Chimica Acta., 520: 19-32.

Block, C.V. (1996): Pharmacokinetics of the cephalosporin antibiotic cefquinome in sows at different stages of the reproductive cycle.

Inaugural-Dissertation,Tierarztliche Fakultat, LudwigMaximilians-Universitat, Munchen,Germany, pp.,148.

Cruickshank, R.; Dugvuid, J. P.; Marmion, B. P. and Swain, R. H. (1975): "Medical microbiology, the practice of medical microbiology" $12^{\text {th }}$ Ed., Vol. 2, Churchill Livingston, edinburgh and New york.

Collee, C. J.; barrie, P.; Marmion, A. G. and Anthory S. (1996): Cited in Mackie \& Mccartney Practical medical microbiology $4^{\text {th }}$ Ed. page 151-178., Newyork EclinBurgh London.

Edwards, P. R. and Ewing, W. H. (1972): Identification of Enterobacteriaceae. Minneapolis, Burgess Publishing Co. pp., 709 .

Guerin-Faublee, V.; Carret, G. and Houffschmitt, P. (2003): In vitro activity of 10 antimicrobial agents against bacteria isolated from cows with clinical mastitis. Vet. Rec., 152: 466-471.

Kageyama, N. A. (1971): A direct colorimetric determination of uric acid in serum and urine with uricasecatalase system. Clin. Chim. Acta., 31: 421-426.

Limbert, M.; Isert, D.; Klesel, N.; Markus, A.; Seeger, K.; Seibert, G. and Schrinner, E. (1991): Antibacterial activities in vitro and in vivo and pharmacokinetics of cefquinome (HR IIIV), a new broad-spectrum cephalosporin. Antimicrob. Agents Chemother., 35: 14-19.

Lorian, V. (1980): Antibiotics in laboratory medicine. $3^{\text {rd }}$ Edition, Wilking Battimore, London, page 265-297.

Maha, Z. G. (2005): Pharmacokinetics of cefquinome and tissue concentration in broilers. Bull. Fec. Pharm. Cairo Univ., 43( 2): 201-207.

Preston, D. A. (1992): Overview of the development of a new class of $\beta$-lactam antibiotics: the carbacephems. The Antimicrobic Newsletter, 8: 58-63.

Rose, M.; Thomas, V. and Nordmann, P. (2004): In vitro activity of third and fourth generation cephalosporins against E. coli strains expressing plasmid-encoded AmpC cephalosporinases. In: Risk Management for the Limitation of Antibiotic Resistance, Scientific Symposium. 15-16 November 2004. Federal Office of Consumer Protection and Food Safety, Berlin, Germany.

San Martin, B. N.; Bataglia, J.; Hernandez, P.; Quiroz, A. and Canon, H. (1998): Absorption and excretion of cefquinome in Coho Salmon (Oncorhynchus kisutch) in freshwater at $10^{\circ} \mathrm{C}$. J. Vet. Med., 45: 615-623.

Reitman, S. and Frankle, S. (1957): Determination of serum glutamic oxalacetic and glutamic pyruvic transaminase. American Journal Clinical Pathology, 28, 5658.

Snedecor, G. W. (1969): Statistical methods, $4^{\text {th }}$ Ed. The Lowa State Univ. Press, Ames., Lowa, USA., page 91.

Suhren, G. and Knappstein, K. (2003): Detection of cefquinome in milk by liquid chromatography and screening methods. Analytica. Chimica. Acta., 483: 363372. 
المسار الحركي وبعض الجوانب الفارماكوديناميكية لعقار سيفكينوم في الدواجن

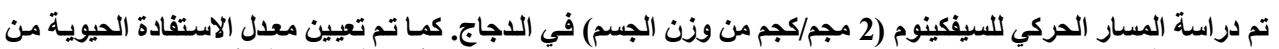

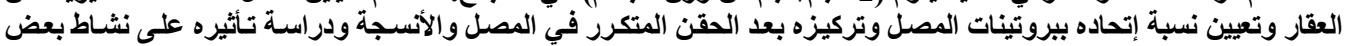

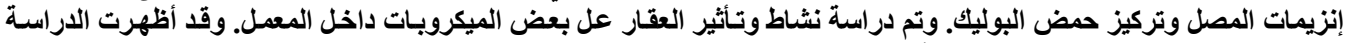

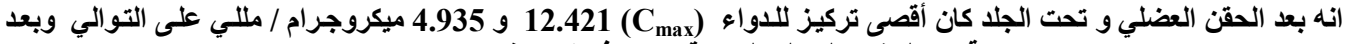

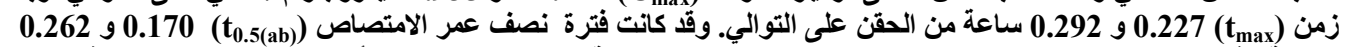
سـاعة وفترة نصف عمر الإخراج (t)

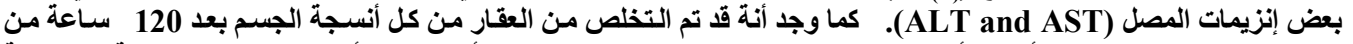

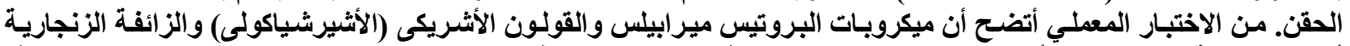

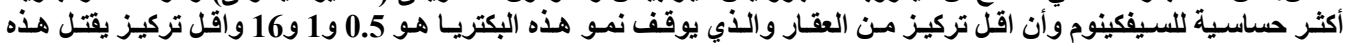
البكترياهو 16 و16 و>128 على التوالي. 